\title{
Silence as a way of knowing in Yolngu Indigenous Australian storytelling
}

\section{Caroline Josephs}

I am, in this chapter, approaching three aspects of silence as a way of knowing — in relation to Yolngu story and storytelling — through one particular Yolngu story which I cannot tell. What I can tell - is why I cannot tell the story, and how pursuing the question of whether I could tell the story, and in what way, led me on a long intriguing journey.

The three aspects I want to deal with, in relation to one Yolngu story, are:

1. protocols of being silent around storytelling - or not telling;

2. inside/outside knowledge, and touching into the silence surrounding, and in women's business; and

3. embodiment as a silent way of knowing when dancing country.

\section{The way of storytelling}

My approach is a step towards Yolngu ways of being and telling as far as may be possible for a non-Indigenous non-Yolngu storyteller and researcher, and to make the bridging necessary for a similar audience as myself. Yolngu epistemology is part of what I am terming sacred epistemology - a mystical tradition which includes phenomena such as revelation and epiphany, and of being present to the seen, the known, and at the same time, to Mystery, the Unknown, the 'between', the 'ship' of relating. In this process, being becomes Being, for Yolngu. It is also primarily an experiential approach to knowing, a felt sense in the body, and can not in my view, be met through analytic conceptual frames of reference. According to Greg Dening, ${ }^{1}$ story is the only way such a sacred world may be represented. Current experiences are sung and told as contemporary expressions of the Dreaming, the moving from the Wangga to the present. Past and present thus become fused and ensure a future of deep intimacy with all beings.

My way of presentation is to work towards exemplifying such approaches - through personal story (never separate from Yolngu 'history' or Dreamtime story) and traditional storytelling, in ways that represent relationship with country, and with all beings, including kin with others of clan and tribe. I weave 
these storytellings with explanation in the non-Yolngu tradition to make the connections clearer for we who are non-Indigenous readers. Knowing, for Yolngu, is always being approached as an interior experience for the individual, albeit in the context of the tribe's cultural knowledge - it is as a consequence always done within silence. Outside or exterior experiences will always be parallelling interior internal experiences in symbolic ways, in feeling states and in states of mind. Storytelling is always intending to link each Yolngu to their own country, to plants, to animals, to all the Dreamings, and to each other, in particular kinship interrelationships which are articulated not only through storytelling, but are constantly reinforced through an elaborate and refined 'opera' of mark-making, music-making, protocols of relating presented in everyday life and ceremony both. (If you are my mother-in-law for example, there are certain kinds of body language to be presented in your company, and only certain kinds of humour may be displayed with certain family members). So, I am presenting a methodology pointing towards Yolngu ways of knowing at the same time as telling the stories.

\section{The people, the place, the story}

Yolngu people are Indigenous Australians living on their land which is in north-east Arnhemland, of Australia. Australian Aboriginal people have been on their land continuously for perhaps 40,000 or more years. (Yolngu language is probably around 5000 years old). Yolngu came into first contact with white people in the 1920s with a few anthropologists who travelled by boat to the remote area, in the 1930s with the establishment of a mission school, and with the impact of the multi-national bauxite miners, in the 1960s.

As a necessary precursor I am telling of the journey that led me to this Yolngu story. The story, commonly called in Arnhemland, The Wagilag Sisters Story, is a story of the Rainbow Serpent. Yolngu personal stories are bound together with ancestral stories. Narrative (or 'story') is inextricably woven with country, and body to country, and all beings to each other and to country through the laws of kinship.

In 1979 I met Wandjuk Marika, an Elder, important Law man, master yidaki ${ }^{2}$ player, artist, from north-east Arnhemland - at a conference in Darwin where I was talking of the project I was running at the time across Australia. I was offering a presentation on 'The Curriculum Development Centre's Multi-Arts Project' in terms of the rainbow, with its many colours and strands. After, Wandjuk came up to me, shook my hand, and thanked me for the story of the Rainbow.

We sat in the garden for several hours (I don't recall how long — clock time ceased) as he told me stories of his life and, in the course of this, gave my children Aboriginal names. (It wasn't till decades later I learned the significance of the 
names and the relationships which they implied). Wandjuk told me three stories from his country, a thousand miles to the east in Arnhemland, including one of the Rainbow Serpent. Wandjuk was, what some anthropologists call, a 'bridge person' for his people, keen to describe his culture.

More than 20 years later, I was living in the bush in solitude on the south coast of New South Wales. It was an unprecedented year for pythons. I had never seen so many in the 25 years I had been visiting the place. Three snakes came to visit.

The first - huge - made its way up the Angophera (a native Australian tree) outside my window, and made its way through a hole and into the ceiling. It was to spend the winter there, no doubt attracted by the possums who inhabited the ceiling space during the day, too.

Another python, about six feet long, twined itself into the door jam and prevented my exit from the top storey to the outside deck, and downstairs to the bathroom. I stamped and 'danced' on the floor inside the door, 'Go away! Go away! This is not your place!' I told my not-welcome visitor. Strange echoes resounded - of the Wagilag Sisters. Much later I realised the parallels. In one part of the story, the sisters are singing and dancing to keep the snake from the door of their hut. Aah!

The third snake manifested when I arrived from Sydney to set up the house for a visit by Uncle $\mathrm{Max}^{3}$ and a group of people. Uncle Max was to lead us up Gulaga, the sacred mountain of the Yuin people on the south coast, visible from the back cliff behind my home - known to the Yuin as 'pregnant woman with her feet in the sea'. (One of the sisters is pregnant in the Wagilag Sisters Story). I opened up the house and went on to the front deck. There on the threshold was a complete python skin - a gift - a word of poetry — evoking a shedding of skin, transformation.

Snake stories invaded my dreams. Snake stories arrived in different guises.

I recalled the Rainbow Serpent story Wandjuk had told me so many years before. I went down to the garage and found my 1979 journals and re-read the words I had written of my meeting with Wandjuk.

The snake visitations also led to a long conversation with an Aboriginal woman (not a Yolngu), at the end of which she said she thought I could tell the story and use my good judgment about what to tell. ${ }^{4}$

That was before I visited country of the story. I wasn't sure. It was early days. I read a number of versions of the story, and everything I could lay my hands on about Yolngu country and culture.

This story of the rainbow serpent is a living story I cannot tell. I am obliged to be silent on it. I only learned of the protocols surrounding this 'big' story 
while delving into the question of whether I could as a non-Yolngu researcher and storyteller tell the story. In the process of living with the question, I talked with many people. Why, I wondered, was it that I could not tell the story? After two years of talking with many Balanda (or non-Yolngu) people who had lived with Yolngu and worked closely with them, I found out about what may be called, 'protocols', in relation to the story.

\section{Protocols}

First, the story emerges out of the country of Arnhemland - the story track (or songline) moves from south-east to north. It intersects with another big creation story of another moiety. (Each story, as well as every person, every creature and every thing in Yolngu culture, belongs to one of two complementary moieties, either Yirridja or Dhuwa). The story is associated with three major ceremonies for both men and women. (Sometimes ceremonies are held separately, e.g., around menstruation and in former times, childbirth. Some major ceremonies are held for all.) To tell it out of country makes no sense, as the story, like the serpent, follows the route of Yolngu Ancestors as they travelled through specific country, which includes for example, the waterhole of Mirramina, in central Arnhemland.

Custodians of the storytellings are elders from five major clans. The place of the country where a storytelling is held will determine which part of the story will be told. It would never be told in what we as 'whitefellas' would assume to be its complete form, or any form we might find in a written 'text'.

The tellings would be carefully negotiated among the clans for a ceremony, ensuring that all clans would be agreeable - this is part of a bringing together and making of relationships of community, through preparation and negotiating processes. The parts of the story and the ways in which it would be told would depend not only on these factors, but the purpose for telling (for initiation, for funeral or another ritual or event), the people present, their ages, gender, and kinship with others, with the country, who the teller is, the relationship with Dreamings in the story. In addition, kinship (or relationship with all, and with other beings and humans) is mapped by the land - gurrutu. It interweaves and overlays everything.

The story in its oral forms - which traditionally it always is, perhaps accompanied by singing, dancing, mark-making on bodies — in a kind of multi-strand 'opera' of many senses. It is fluid and changing, dynamic, just like the Ancestors, moving through country, changing form many times transformations that create country and are created out of country. The same story would never be told on two occasions. It changes. The important elements will however, be present. 
I was told by Sophie Creighton, an anthropologist who has worked with Yolngu, that there are important distinctions also between the right to hear a story, the right to tell a story, and the bestowal of a story. ${ }^{5}$

Peter Sutton, a South Australian linguist writes: 'Ancestral Beings are Stories and their Sacred Dwelling Places are Story Places. ${ }^{\prime} 6$ When I first saw this brief inscription on some artefacts in the Museum of Australia in Canberra, I stopped dead in my tracks! Something happened in my body. I did not know what it was right then. The sentence would resonate in me for a long time.

What I finally discovered after some time was that my notion of someone telling a story, was not what it was about - the Ancestors (who are Beings, not necessarily only human beings) are the stories — and each is intimately dwelling as Place (in country). The tellers become the Ancestors, those who body forth in dance as Ancestors.

This turns our ordinary notions upside down — and inside out — which brings me to 'inside' and 'outside' knowledge among the Yolngu. I take this up later.

Here is, however, the version of the story which is an acceptable form; a public or outside version. It has been carefully worded by Yolngu. Each word is full of significance, layers of meaning, though it is framed in ways that avoid much detail of other now unable-to-be-public versions. This version I came to designate, a 'fixed version' to distinguish it from 'living versions'.

The story covers the territory of a number of clans, in particular the waterhole named Mirarrmina on the Upper Woolen River in Central Arnhemland. The waterhole is the home of 'Wititj' the Olive Python (sometimes also known as the 'Rainbow Serpent'), one of the most powerful of ancestral beings. 7 Accounts of the story vary with context and narrative, but the following details (the text tells us) occur in most versions. ${ }^{8}$

\section{The Wagilag Sisters Story - A fixed version}

Two sisters, the older of whom has a child, the younger is pregnant, are fleeing their home in the south-east. They are being followed by clansmen. The Sisters reach Ngilipidji, or the Stone Country of the Wagilag clan, from where they get their name. As they continue on their travels they encounter animals, plants and country on which they confer names, in essence bringing them into being. They decide to camp in the rich and fertile country surrounding the waterhole at Mirarrmina.

According to some versions of the narrative, one of the Sisters pollutes the waterhole, which arouses Wititj from his sleep. The younger Sister gives birth, further inciting the Snake. Unsuspecting, the Sisters make camp, build a bark hut, and try to cook the food they have caught, but 
things begin to go wrong - the animals and vegetables come to life and leap into the waterhole. Wititj emerges from the waterhole and creates a storm cloud with lightning and thunder to wash the Sisters into the well. The land is flooded as the first monsoon pours down its rains.

Frightened, the Sisters perform dances and sing sacred songs to deter the Python.

Finally the Sisters drop in exhaustion, and Wititj is able to enter the hut and swallow them, their children and their dog.

Shortly afterwards, the great Wititj develops a terrible stomach ache. He rises into the sky above the flooded landscape, and his groans attract the attention of other great Snakes from surrounding clan estates, who also rise up into the sky. They talk to each other and discover they have different names. When asked what ails him, Wititj lies about what he has eaten, realising that he has probably eaten beings of the same moiety. Finally, the pain becomes so great that he falls to earth and vomits the Sisters. (He retains the children, who belong to the opposite moiety, the Yirritja). When the Sisters are brought to life again by the bites of the stinging caterpillars, Wititj beats them with clapsticks (malirri), and swallows them again.

The Sisters' clansmen had followed them and were asleep by the triangular impression made in the ground by the Python's fall. The sisters come to them in a dream and reveal the secrets of the sacred dances and songs they had composed in their efforts to stop the rain.

This is the version of the story I was told by a number of expert informants ${ }^{9}$ that I could tell and write.

\section{'Outside' and 'inside' knowing}

Almost two years after the big snake year in my south coast home I was invited to Arnhemland as part of a Music Forum (to include a small group of around 25 Balanda (non-Yolngu) anthropologists, ethnomusicologists, and an assortment of others like myself, an educator, with groups of Yolngu dancers and singers presenting and speaking) - to be followed by Garma, a festival - the occasion of Yolngu sharing their knowledge more widely with Balanda as public or 'outside' knowledge.

Howard Morphy, a much respected anthropologist who has worked with Yolngu for many years, says: 'The delicate and complex relationship between inside and outside [knowledge] provides the context for understanding the release of knowledge to Balanda.' 10 'Outside' knowledge for Yolngu (according to Morphy) is analogous to 'inside' knowledge which is secret and sacred. There are layers to this knowledge - indicated by the kinds of words that are used 
in the storytellings for example. There will be other differences of course too. The public versions will use different words, not so-called 'power' words. Mandawuy told us, for example, of 30 words for the turtle, all with subtle variations and meanings for Yolngu.

Early in my explorations around the Wagilag Sisters story, I spoke with Nigel Lendon, who had curated the large exhibition of paintings representing 60 years of bark paintings of the story. This was held in the Australian National Gallery in 1998. As I spoke with him of the story, he stopped me suddenly. 'You know', he said, 'If I had used the word you have just used as the name of the snake in Arnhem Land, it would have meant death!' He told me of being stalked while in country. Curators had spent seven years negotiating the release of the story in a suitable form to be published in the exhibition catalogue. I felt distinctly uncomfortable at this news.

Later, I recounted this conversation to Howard Morphy. What did he think? In his understated way, he said: 'I think that is a little exaggerated'. However, Alan Fidock, with whom I had worked in Canberra over many years, and who had lived and worked with Yolngu for 13 years in Milingimby, agreed that I could not utter this name, a 'power word'.

What to be silent about, and what to speak? I knew I would have to move slowly and with sensitivity. Speaking could have certain very serious consequences. I did not wish to offend. I was getting conflicting messages. And women anthropologists had different ideas again about what could and could not be spoken! ${ }^{11}$

Much later I was to learn from Howard Morphy:

Power names are called publicly at important stages of ceremonies the whole time, e.g. the thirty words for turtle are not used in mundane contexts. And the word you refer to as not being able to use - are used only in restricted private contexts. However very few words fit into this category. Most powerful names are known but treated as special. The silence or the interval between their sounding marks their significance and creates a sense of awe in their presence as well as the aesthetic power of their performance. ${ }^{12}$

Later, at the Music Forum at the Yothu Yindi studio on the Bay in Arnhemland, I asked Mandawuy a question about colour and body painting. He spoke in language to others, and eventually came back with an answer. What was the consultation I wondered? Perhaps, how to explain in terms appropriate to my level of understanding? I learned that one principle is to show respect, always ask if unsure, but on the other hand, only ask a question once. Later I found when I became closer to Gulumbu, I would ask her questions and she 
would simply turn slightly away, as though she hadn't heard, and then I would know not to pursue this line of questioning.

Gregory Bateson says: 'Secrecy can be used as a marker to tell us that we are approaching holy ground...' 13 Bateson's proposition is that secrecy (or the non utterance of certain things) was essential in the epistemological process. He says there is a 'necessity for the sacred':

This is a very important and significant matter, that non-communication of certain sorts is needed if we are to maintain the 'sacred'. Communication is undesirable, not because of fear, but because communication would somehow alter the nature of the ideas. ${ }^{14}$

'Communication of certain things alters the nature of the ideas.' Silence, or 'non-communication' is required for the 'sacred', Bateson maintains.

Howard Morphy tells us more, specifically in relation to silence as a way of knowing in relation to Yolngu knowledge:

And in many respects the layering of knowledge can be thought of as a pedagogical [or learning process] technique, though it is one that emphasises the variability in understanding that exists at a given moment among different members of the society. The layering is as important as the secrecy. ${ }^{15}$ [my emphasis]

According to Morphy, it is not only the nature of the ideas, but the nature of the process for learning which renders silence significant. Both layering and silence have pedagogical intent, are part of the learning process. 'Inside' and 'outside' knowledge are seen to be different in Yolngu terms. Outside knowledge is freely available. (There are 'inside' and 'outside' versions of stories). 'Inside' knowledge is available only to certain people at certain stages, in certain circumstances. It is revealed in phases, with pauses, with silence between, as Morphy has indicated - a necessary part of a sacred epistemology or way of knowing.

Morphy indicates that the concepts of 'inside' and 'outside' are more than the English concept of 'secret'. 'Inside' for Yolngu is used, he says, in two complementary senses. The first is 'inside' in the sense of truth or generative power. The other is 'inside' in the sense of exclusive or secret. In the first, women and men are equally included. In the second, women are excluded from certain contexts and certain knowledge. ${ }^{16}$ The Wagilag Sisters Story seems to hold both kinds of knowledge. This explained its being associated with both men's and women's business.

What Morphy has not articulated is that Yolngu women also hold certain knowledge secret from the men — certain women's business knowledge. ${ }^{17}$ Rita Gross (1977) makes a strong case that men's and women's rituals, symbols and 
knowledges are always equal and complementary, without gendered hierarchy, 'co-equal and co-necessary'. ${ }^{18}$ She refutes any sacred/profane dichotomy of male/female in Aboriginal religion and argues instead that the 'correct interpretation is to see women as embodiments and manifestations of a different kind of sacrality than that associated with males'. She notes that 'women's experience is inaccessible to males in the absence of articulate females'. Women's experience has not been fully articulated from within Aboriginal cultures. ${ }^{19}$ I would argue that this is part of an 'unspoken story', a story silenced or silent, another story that has not been told; another aspect of 'silence'. This is the unknowable by one gender, of the other. Rita Gross goes further. She looks deeply into the Wagilag Sisters Story to conclude that 'women's unique experiences are potent metaphors in men's religious lives'.

Another important point to be remembered is that while 'outside' or public or children's versions may be simpler in form, they reflect, or are analogous with, the 'inside' knowledge, though this may not be immediately evident.

Helen Verran, a philosopher now working at Charles Darwin University, says:

Yolngu knowledge is the intrusion of the Dreaming into the secular. The Dreaming is brought into the here and now by the doing of particular things at particular times by particular people...Knowledge can only ever be a performance of the Dreaming, a bringing to life in the here and now of the elements of the other domain. ${ }^{20}$ [my emphasis]

'Dreamtime' in Yolngu is called Wangarr, and each language group will have a different term which is only approximated by the English term, 'Dreamtime'. Knowing in Yolngu is not about words, or descriptions, or abstract concepts. It is more related to being and actioning. I will return to Helen Verran's notion of 'performance' indirectly, through the dancing, a little later.

I could, (I was assured by Alan Fidock, Djon Mundine, Nigel Lendon, Sophie Creighton), write of the story and tell the story which had been carefully negotiated and published.

Revelation and epiphany are ways of knowing in Yolngu culture. ${ }^{21}$ Such 'events' happen in silence. What is revelation? It is the known being connected to the Unknowable in such a way as to open up to all possibility.

In Yolngu culture, Bir'yun is a shimmering effect (seen in finely cross-hatched paintings) may occur through an experience of what may be termed 'epiphany' or 'revelation'. Bir'yun projects a brightness that emanates from the Wangarr Ancestral past which manifests in the present through storytelling, singing, art-making, dancing — or from the Ancestral Beings themselves. The brightness of bir'yun endows the painting with 'Ancestral power'. 
This process probably has to be present in the painter in order to evoke it in the viewers. This may echo the state that has to be present in the storyteller for the effect to transmit to the audience during a storytelling. The process is similarly evoked in other forms of expression and sacred art in Yolngu (dancing, singing), where Morphy reports that there is a progressing from dark to dull, to light and brilliant, analogous to the transformation that arises in the process. It is present in the music which builds to a final shout, for example, as well as in the dances which sometimes build to a frenzy of dramatic and solo performances (especially as I noted, with the male dancers). I make the parallel of bir'yun with storytelling and my own experiences later in country.

Raymattja Marika-Mununggirity, Yolngu linguist from Yirrkala, has written of the relationship between the 'mythic' ancestors and the life that is currently lived by Yolngu:

Knowledge is living, and it comes from a real world, it has real life, real events and real happenings. That's what happens with the old ancestral stories, we still relive that past history, we still sing it, dance and still bring it and fit it into the present. That's what makes the present world a meaningful world to live in. ${ }^{22}$

Past and present exist together, ensuring a future conserving the Ancestral states of Being, and are given meaning and significance through re-enactment.

Revelation transforms, transmits, opens up being into Being, opens up into all possibility. Where creatures can jump out of a fire, and run and jump into a waterhole, as in the Wagilag Sisters Story, transformation has occurred. Ancestral Beings can transform in such a way - where an experience is charged - as well as in a myriad other ways, and Yolngu re-enacting Ancestral Beings re-embody that transformation. In re-storing the behaviours of the Ancestral Beings, Yolngu re-story their own being creating Being, maintaining connection with Ancestors.

Howard Morphy, in writing of the nature of Yolngu knowledge, talks of the revelatory nature of Yolngu knowledge and its relationship with secrecy. He uses the word 'transmission' in this context. Transmission of knowledge assumes a direct experiencing, a taking in, a knowing through embodying or 'immediate presencing $^{\prime 23}$ of that knowing.

Morphy points out that the phasing and structuring of knowledge through secrecy and through revelatory knowing - establishes a rhythm, that allows slow digestion or absorption, to occur (in the way that snakes digest their food). There are thresholds at each turning, structured by secrecy. Secrecy can 'mark division between inside and outside knowledge'.

Within such a story as the Wagilag Sisters, the potential exists for many layers of meaning in different contexts. As Nigel Lendon has pointed out - 
there is no one meaning for the story - meanings shift in relation to context, juxtapositionings, and a particular moment in time:

The search for a singular 'deep' authentic meaning is doomed to failure. Thus the greater interest for developing a knowledge of these works [paintings of the Wagilag Sisters Story] is in the potential for elements to carry multiple meanings, in different contexts, conjunctions and historical moments. ${ }^{24}$

In Yolngu culture, all is dynamic in relation to the Story or Story versions. Contiguous elements and multivalent significances are part of the storytelling.

I had come to understand that I could not tell the Wagilag Sisters Story in any way I chose. I held no authority to tell. Not telling underscores the importance of some secrets, the mysteries that cannot be spoken.

In Yolngu society, I cannot assume a right to know. I must wait, listen, until invited into various aspects of the assembling of understanding through action, relationship in the environment in concert with others, with creatures, through listening, through ritual, ceremony, through the body, through dance, through the remarks people casually offer, and in all the details of everyday life.

Story is therefore history performed. And, as Ancestors enact transformation, so contemporary Yolngu re-create or re-enact the transformations as they tell the stories, sing the songs, do the paintings on bodies, and dance the dances of the Ancestors. Storytelling is in this way transformative for those who participate. In Yolngu terms, a storyteller can produce a storytelling, but it is Reality that is presented, not just a story.

Let me tell you of one experience that I had at Garma.

First, the landscape.

We are on a vast bush site, a stringbark forest on top of the escarpment. Between the trees, the deep red earth appears. If you walk a few hundred yards to the edge of the escarpment you can see the sea in the distance. There are five hundred Balanda and five hundred Indigenous people (many from vast distances across the north of Australia) camped in tents dotted in among the trees. A large space opens up among the trees, covered by beach sand - the shape of a long triangle and almost as long as a football field - where the bunggul takes place, late each afternoon. The bunggul is the ceremonial singing, dancing, storytelling that happens each year of Garma. The 'boss man' of the ceremonies and the storyteller for Garma bunggul is Galarrwuy Yunipingu.

For much of Garma I have spent time sitting on the ground with the women in the Women's shelter, learning how to make string, making friends with the women, telling our stories to each other, and gradually getting to know Gulumbu, with whom I share an instant and easy rapport. 
And so, to the story...

\section{Silent embodying, dancing as re-enacting story}

Franca Tamisari writes:

Dancing establishes relationship between people, country and ancestors as well as between the participants in a ceremony... In Yolngu dances 'the body speaks - directly and in its totality' of our being-in-the-world and being-with-others. ${ }^{25}$

Let me remind you of a part of the Wagilag Sisters story:

Frightened, the Sisters perform dances and sing sacred songs to deter the Python. Finally the Sisters drop in exhaustion, and Wititj is able to enter the hut and swallow them, their children and their dog.

The Sisters come to [their clansmen] in a dream and reveal the secrets of the sacred dances and songs they had composed in their efforts to stop the rain. ${ }^{26}$ [my emphasis]

It is the Sunday after Garma has finished, and most of the Balanda have gone. My companions from the Music Forum have gone to a motel, but I choose to stay on at the campsite, not wanting to sleep inside if I can be in the bush. I have tried to get an earlier flight out, unsuccessfully. I have heard today there is to be a ceremony, but I don't take too much notice, as I imagine it will be held deep in the bush, away from the eyes of myself, or other Balanda.

A handful of Balanda are still there at Gulkula, the Garma site, and about 300 Yolngu - gradually drifting into the bunggul 27 space.

It is hot in the sun. I have been collecting tea in large tin cans for the women, for Galarrwuy, for the women in the weaving shelter, back and forth in the heat to the kitchen, finding cups and sugar and milk to bring for them. It seems appropriate to tell Galarrwuy as I bring him tea, 'Gulumbu says I am yeppa (sister)'. He has shown us the elaborate head-dresses and armbands that will be for the boys, woven with coloured feathers. 'These must be special', I say. 'Special', he acknowledges, as he gently puts them back into a bag. Increasingly, it is emerging, that the ceremony will take place here in the bunggul space, for two boys from two clans, one of them Galarrwuy's son.

I go to join the women, as Gulumbu has invited me to do, sitting in the women's shelter near where she is tending the fire. She leaves me in the care of her daughter, Dhambit. Gulumbu, I realise only later, is Galarrwuy's sister. Kin establishes obligations, responsibilities, roles, everything. I observe that she has a leading role to play in the unfolding event. 
The groups for singing and dancing have assembled on either side of the ceremonial space where the evening's bunggul for each day of Garma have, it seems, been gradually building to this climax.

In shelters ${ }^{28}$ on opposite sides of the performance space where the figures of Ganbulapula ${ }^{29}$ and a great funeral log stand, sit the groups of the two related clans. To the accompaniment of yidaki and clapsticks, they sing, each clan alternating, and the men and women of each clan also take turns to move into the performing space to dance in the sequence occasioned by the ceremony.

Eventually, I am told, the two boys from the two clans will emerge from the bush at one side, accompanied by the older men of both clans, to be ushered into the space for the climax of the initiation ceremony and circumcision. They are being prepared, painted up, in Yirrkala, the Yolngu town some distance away.

I stand near Gulumbu, tired now of sitting still in one place with the women in the shelter for most of the day, as the singing and dancing go on, and preparations around the bunggul continue. A great turtle is being roasted in the ground. (Gulumbu calls to me to come and look). It will later be fed to the clan elders at the end of the ceremony.

Gulumbu is tending the fire that is to be used for the 'smoking' of the relatives, ${ }^{30}$ and for boiling the 'treatment' for the boys, following the ceremony. I get up, stiff, and beginning to feel my body mightily in need of movement after four or five hours of sitting still. I have been saying to myself to just observe, not ask questions on this special day, to be grateful to be present (which I certainly am) and wait. I cannot sit still any longer. My body won't allow it. I get up and walk across to Gulumbu at the fire. Standing opposite her as she stirs the 'treatment' over the fire, I begin to move my body a little as I see the women doing in the central sandy space.

I am itching to be dancing, restless from being still for so long.

Maarr, which manifests itself in the footprints left behind by ancestral beings in the landscape features, names, objects, designs, songs and dances - is not only ancestral power, it also refers to people's innermost feelings of love and care, silent wishes 'which make things happen', concealed desires which are not expressed but which nonetheless are felt and met. ${ }^{31}$ [my emphasis]

I have always loved to dance almost more than anything else, and it is always hard for me to be on the periphery of any dancing, painful to be looking in, unable to participate. I am unsure of the codes here. I have been sitting in the shelter observing, cautious of moving or of asking questions, conscious that I am privileged to just be here watching, conscious too, of Gulumbu's having made my entry possible. 
'Can you teach me the dance?' I ask Gulumbu. I do know this important principle of being in Yolngu country. Always ask. Be respectful. I have also been cautioned by a Balanda who has worked with Indigenous people for years: 'Don't ask more than once'. I can never know if what I am asking is crossing an unknown boundary. I am risking something, transgressing the boundary of being still, being quiet, just observing. It is risky business. But I trust this woman, her presence, her warmth. I have put on the armband she has made me. I am wearing the string with possum fur inserted into it she has given me.

Gulumbu looks up from her work of stirring the pot with the stringybark in it for the boys, straightens up from her task, then turns and gestures to the far side of the ground, 'You go right around the outside to that other side. Keep right behind, and do the dancing there'.

With her blessing on the enterprise giving me permission and courage, I walk carefully around the outer rim of all the people and the activity in the middle of the sandy performance space, trying not to run in my impatience to be dancing - to where the group of women are seated in another shelter, as they rest in between each segment of dancing. A tremor in my body. I am moving at last always for me, a favoured state.

When the women of this clan get up again to dance, I kick off my shoes and begin to mimic them, staying well back in the background from all the people.

I have positioned myself where I feel myself to be solitary, inconspicuous, unobserved. There are only Yolngu here, but their attention is focused on what is happening in front of me, in the bunggul. I am well behind them all. I am enclosed in concentration, focused on being present to just the dancing. I have the dancing group of women firmly in my sights through a kind of soft focus vision, imitating as closely as possible their every movement - allowing my body to dance the movements, being there, simultaneously as it is happening. It is something I have learned to do - to let go and mirror the movements, be the moving bodies there, with my body-mind, here.

So it is startling for me to hear what next takes place in the sequence of events.

I have been dancing for just a few short moments alone, but in unison with the group a little distance away in the performance space. The lead dancer turns her head, continuing to dance as she does so, and calls over her shoulder to me, 'Come into the canoe with us!'

At the sound of her invitation, and without a nano-second's hesitation I leap into the performance space (it feels in many ways a great 'leap'), keeping my body and mind open to picking up the steps and the rhythms as they are done, moving with them. I am alert, but relaxed, excited, keeping my peripheral vision open, breathing into my belly and letting the body know, forgetting any thinking 
about this strange and daunting thing I may find myself doing, if the focus stumbles. It is my body which is the dancing, the knowing.

The reality of Yolngu performance, and especially dancing, is thus one of epiphany and transformation in which relationships with place and people are established, lived-in and embodied by the dancers. ${ }^{32}$ [my emphasis]

I am aware of the other Yolngu women dancers, though I am focusing on the lead dancer. I am in line with the women. The lead dancer is in front of the other dancers, closer to the singers, and seems to emit the dance calls and to direct the dancers.

I am kicking up the dust with my feet touching the earth and sending dust rising as each foot turns in and up slightly to the inside with each step. (This is different from the men's 'hitting' the earth with their feet). The dust itself reminds me of a liminality of body meeting the country.

As the meaning of footprints can be said to reside in between, that is in the social, political links and emotional bonds they fashion between places and ancestral events as well as people and country, the meaning of dancing is between the steps, between the participants of a ceremony, the inter-subjective space of desire and compassion, love and competition, that one enters through dancing. ${ }^{33}$

My hands follow the dancers' movements. I bend slightly forward as they do, and turn as they do, re-enacting and re-embodying the journey of the Ancestors, re-storing it to the present, re-storying it in the present.

I am dressed all in black (with long white hair); they are in colourful dresses, their dark skin glistening in the sun. This country, this story, these people, this dancing, myself Balanda, here with Yolngu, now, all related, storied, in the dance.

My hands gesture the different aspects of being in the canoe. Just dancing, just following, being with the whole group of women, allowing my body to keep in tune with the lead dancer who gives signals for changes in the movements. I can just do it by focusing my attention and at the same time opening to the body and the vision of being with what the women are doing.

With a sharp shout the sequence is finished and we all retire to sit down and the women laugh and chat among themselves in language, a language I wish deeply to understand.

Corporeal connection is enacted and elaborated in the cosmology of Yolngu people in Northeast Arnhemland through images of bodily transformations, journeys and traces...the body as the 'hinge' between self and the world underlies the idea of ancestral power and the experiential character of Yolngu knowledge. ${ }^{34}$ [my emphasis] 
In the dance, the body provides a silent hinge between self, world, ancestral powers - through embodiment of ancestral power and ways of doing things. I was, though I could not reflect on it at the time, stepping directly into this embodying by being in the dance with the Yolngu women. No matter that I did not comprehend. I was enacting the story that was the story coming in the dance. I was in the canoe ${ }^{35}$ with the women, travelling with them, in the in-between space and time between their culture and mine, between Ancestral Past and contemporary time at Gulkula and between that time and the writing now. Something of a liminal silent gap quality invoked this transforming — unplanned, unforeseen, startling.

My footsteps had taken me to Darwin and the meeting with Wandjuk so long ago, to Garma, and to meeting Gulumbu, Derrkngu, Rarriwuy, Wityana, Mandawuy, Raymattja, and other Yolngu people, and into the dancing. All of these events were connected it seemed to me, in tracings, in footsteps on the country, connected through a kind of silence, the in-between and ultimately in the embodiment that occurs as dancing the country.

I had traversed three kinds of silence to reach this place: the protocols of storytelling for Yolngu, the understanding of the parallelling of inside and outside knowing, and a culmination of stepping into and dwelling as ancestral spirit with the Yolngu women. All three kinds of silent knowing had coalesced and actualised in the dancing, and in the embodying of the stories in the land and of the land that had birthed them.

I left Garma with the dust of that place, Gulkula, on my feet.

'We are here now; we are the voice of the serpent,' say the Wagilag Sisters.

'Now I give you my ceremonies', says the Snake, with their voice. ${ }^{36}$

\section{Endnotes}

1 At a conference on 'Writing the Sacred', The Australian National University, October 2002.

2 Commonly called in the southern areas of Australia, 'didgeridoo' - a long hollow log instrument with a deep wind sound.

3 Dulumunmun, Yuin Elder of the South Coast of New South Wales.

4 From Tranby Aboriginal College in Sydney.

5 I could find no written source for this information.

6 P. Sutton, 1988, Dreamings, The Art of Aboriginal Australia, New York: Viking/Penguin, p. 19 (my emphasis). Sutton is writing of Cape York, but the same idea applies for Arnhemland.

7 W. Caruana, and N. Lendon, 1997, The Painters of the Wagilag Sisters Story 1937-1997, Canberra: National Gallery of Australia, p. 9.

8 Ibid., p. 9.

9 Nigel Lendon, Djon Mundine, Alan Fidock, Allan Marrett, Sophie Creighton - experts on different aspects of Aboriginal and Yolngu culture.

${ }^{10}$ H. Morphy, 1991, Ancestral Connections: Art and an Aboriginal System of Knowledge, Chicago \& London: University of Chicago Press, p. 98. 
11 Two Canberra-based women anthropologists told me that as the story was in the public domain I could tell it. (They had not however, worked specifically with Yolngu, but with other Indigenous Aborigines.)

12 Personal email, May 2006.

13 G. Bateson, and C. M. Bateson, 1987, Angels Fear: Towards an Epistemology of the Sacred, New York: Macmillan, p. 97.

14 Ibid., p. 97.

15 Morphy, 1991, op. cit., p. 77.

16 Ibid., p. 96.

17 Gulumbu Yunipingu, personal communication, August 2004.

18 Rita Gross, 1977, 'Menstruation and Childbirth as Ritual and Religious Experience in the Religion of the Australian Aborigines', Supplement Journal of the American Academy of Religion, vol. 45, no. 4, pp. 1147-1181, p. 1147, 1150.

19 There are exceptions, e.g., Deborah Bird Rose and Dianne Bell's work in Central Australia, Fiona Magowan and Franca Tamisari in Arnhem Land, Catherine Berndt.

20 H. Verran, 2002, 'Discussion of the Philosophical Issues for Sciences and Scientists engaging with Indigenous Knowledge', Unpublished paper from talk, Garma (my emphasis).

21 H. Morphy, 1989, 'From Dull to Brilliant: the Aesthetics of Spiritual Power among the Yolngu', Man, (N.S.), vol. 24, p. 28.

22 R. Marika-Mununggiritj, 1991, 'How can Balanda learn about the Aboriginal World?' Batchelor Journal of Aboriginal Education, July, no.6, pp. 17-23, p. 24.

23 Dr Tony Swain (Sydney University), expert in both Indigenous and Chinese religions and art, maintains that there is no 'transcendent' in Aboriginal religions.

24 Caruana and Lendon, op. cit.

25 Franca Tamisari, 2000, 'Dancing the Land, the Land Dances through us', Writings on Dance, no. 20, p. 31.

26 The Wagilag Sisters Story, version in Caruana and Lendon, op. cit., p. 9.

27 From bon and bun'kumu kneecap or knee; the knees of the performer moving up and down in the dance stepping are said to be talking (bonwanga). Tamisari, op. cit., p. 35.

28 These are wood and bark-covered areas with sand on the floor.

29 Ancestral figure associated with re-configuring of knowledge.

30 Or cleansing.

31 Tamisari, op. cit., p. 39.

32 Ibid., p. 33.

33 Ibid.

34 Ibid., p. 3.

35 The canoe is part of the Djang'kau Sisters story, not the Wagilag Sisters, but it has an in-between, liminal quality which seemed part of my experience at the time.

36 The Wagilag Sisters Story, version Lenore, Mirelle, Balanda poet who lived in the Northern Territory for a time with Indigenous people. She was unable to locate the sources she used for her more extensive poem when I phoned her in Adelaide. 